\title{
Climate and site management as driving factors for the atmospheric greenhouse gas exchange of a restored wetland
}

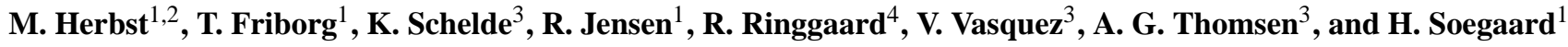 \\ ${ }^{1}$ Department of Geography and Geology, Copenhagen University, Denmark \\ ${ }^{2}$ Department of Bioclimatology, Göttingen University, Germany \\ ${ }^{3}$ Department of Agroecology, Aarhus University, Tjele, Denmark \\ ${ }^{4}$ Orbicon A/S, Roskilde, Denmark
}

Correspondence to: M. Herbst (mherbst@gwdg.de)

Received: 29 June 2012 - Published in Biogeosciences Discuss.: 23 July 2012

Revised: 9 November 2012 - Accepted: 2 December 2012 - Published: 7 January 2013

\begin{abstract}
The atmospheric greenhouse gas (GHG) budget of a restored wetland in western Denmark was established for the years 2009-2011 from eddy covariance measurements of carbon dioxide $\left(\mathrm{CO}_{2}\right)$ and methane $\left(\mathrm{CH}_{4}\right)$ fluxes. The water table in the wetland, which was restored in 2002, was unregulated, and the vegetation height was limited through occasional grazing by cattle and grass cutting. The annual net $\mathrm{CO}_{2}$ uptake varied between 195 and $983 \mathrm{~g} \mathrm{~m}^{-2}$ and the annual net $\mathrm{CH}_{4}$ release varied between 11 and $17 \mathrm{~g} \mathrm{~m}^{-2}$. In all three years the wetland was a carbon sink and removed between 42 and $259 \mathrm{~g} \mathrm{C} \mathrm{m}^{-2}$ from the atmosphere. However, in terms of the full annual GHG budget (assuming that $1 \mathrm{~g} \mathrm{CH}_{4}$ is equivalent to $25 \mathrm{~g} \mathrm{CO}_{2}$ with respect to the greenhouse effect over a time horizon of 100 years) the wetland was a sink in 2009, a source in 2010 and neutral in 2011. Complementary observations of meteorological factors and management activities were used to explain the large inter-annual variations in the full atmospheric GHG budget of the wetland. The largest impact on the annual GHG fluxes, eventually defining their sign, came from site management through changes in grazing duration and animal stocking density. These changes accounted for half of the observed variability in the $\mathrm{CO}_{2}$ fluxes and about two thirds of the variability in $\mathrm{CH}_{4}$ fluxes. An unusually long period of snow cover in 2010 had the second largest effect on the annual $\mathrm{CO}_{2}$ flux, whose interannual variability was larger than that of the $\mathrm{CH}_{4}$ flux. Since integrated $\mathrm{CO}_{2}$ and $\mathrm{CH}_{4}$ flux data from restored wetlands are still very rare, it is concluded that more long-term flux measurements are needed to quantify the effects of ecosystem disturbance, in terms of management activities and exceptional weather patterns, on the atmospheric GHG budget more accurately.
\end{abstract}

\section{Introduction}

The exchange of greenhouse gases (GHG) such as carbon dioxide $\left(\mathrm{CO}_{2}\right)$ and methane $\left(\mathrm{CH}_{4}\right)$ between terrestrial ecosystems and the atmosphere affects the atmospheric concentration of these gases. Potential impacts of land use transformations on the GHG budget are therefore accounted for in international agreements such as the Kyoto protocol. To enable a comparison of the climate effect of individual GHGs, their global warming potential (GWP) is often expressed in units of $\mathrm{CO}_{2}$ equivalents that would have the same radiative forcing effect over a time horizon of $100 \mathrm{yr}$ (IPCC, 2007). In this way the full GHG budget of a land surface is quantified, and the climate effect of the individual gases can be compared. Considering the role of wetlands in the GHG budget of the land surface, there has been an increasing awareness that a carbon sink can be a greenhouse gas source, with $\mathrm{CH}_{4}$ emissions counterbalancing the $\mathrm{CO}_{2}$ uptake, if calculated according to the aforementioned method (Whiting and Chanton, 2001; Friborg et al., 2003; Schulze et al., 2009).

The environmental control of $\mathrm{CO}_{2}$ fluxes above land ecosystems is meanwhile fairly well understood, not least because eddy covariance (EC) observation networks (e.g. Baldocchi et al., 2001) have enabled a global analysis of long-term data that has made it possible to parameterise and validate physiologically based land-atmosphere carbon exchange models for many vegetation types (Houborg et al., 2009). Nevertheless there are still uncertainties in these parameterisations, for example regarding the influence of the water table height in wet soils on ecosystem respiration (Lloyd, 2006; Parmentier et al., 2009) or regarding climatemanagement interactions, since managed grassland sites are 
still underrepresented in EC tower networks (Klumpp et al., 2011).

In contrast, $\mathrm{CH}_{4}$ fluxes have only more recently been included in EC research, and as yet the few available long-term data are highly variable and difficult to interpret (Baldocchi et al., 2012). As a consequence, models of ecosystem $\mathrm{CH}_{4}$ fluxes are not yet as robust, uniform and transferable as those for $\mathrm{CO}_{2}$. Nevertheless the control of $\mathrm{CH}_{4}$ emissions by water table height and soil temperature were already well described $20 \mathrm{yr}$ ago by numerous studies based on chamber measurements, mostly in natural wetlands in North America (e.g. Crill et al., 1988; Roulet et al., 1992; Bubier et al., 1993). Recent advances in sensor technology have meanwhile made it convenient to also observe $\mathrm{CH}_{4}$ fluxes directly at the canopy scale using the EC technique. Several sensor configurations have been proven reliable and robust enough for continuous, unattended long-term studies (Rinne et al., 2007; Hendriks et al., 2008; Detto et al., 2011; Dengel et al., 2011), and the reported fluxes are in good agreement with upscaled chamber measurements (Schrier-Uijl et al., 2010). The EC technique enables in situ observations of potential influence factors on the $\mathrm{CH}_{4}$ flux that are out of reach for chamber studies, such as wind, flooding or grazing (Sachs et al., 2008; Meijide et al., 2011; Herbst et al., 2011a).

As yet there are not many multi-year EC studies of both $\mathrm{CH}_{4}$ and $\mathrm{CO}_{2}$ fluxes (Kroon et al., 2010), and we are not aware of any study that analyses specifically the interannual variability of the full GHG budget rather than its longterm average. This kind of analysis is particularly important for restored wetland areas that are not yet in equilibrium (Waddington and Day, 2007; Höper et al., 2008) and for wetlands that are amenable to management. Despite the advantages of the EC technique it should be noted that for spatially heterogeneous sites only a long-term observation will produce a representative integrated flux estimate, whereas on a short term basis changes in the source area of the fluxes can override their environmental controls (Forbrich et al., 2011; Baldocchi et al., 2012). Thus, a detailed process analysis dealing with the various pathways of $\mathrm{CO}_{2}$ and $\mathrm{CH}_{4}$ emissions from restored wetlands would require an accurate footprint modelling and the mapping of surface properties at high spatial resolution, which will be subject of a separate study. The aims of this paper are (1) to quantify the interannual variability of the atmospheric GHG exchange of a restored wetland in western Denmark and (2) to assess the relative importance of the various climatic and site management factors that control the reported variability.

\section{Materials and methods}

\subsection{Research site}

Skjern Meadows in Western Denmark is one of the largest restored wetlands in Northern Europe. In 1968, roughly 4000 hectares of peatlands, wet grasslands and marshes in the valley of the Skjern River were drained and converted into agricultural land. Between 1999 and 2002, 2200 hectares of this area were restored by refilling the channelised river stretches and excavating a new, meandering river course (Nielsen and Schierup, 2007). The study site is located on a floodplain not far from the mouth of the Skjern River where the soil is dominated by Fluvisols, according to the FAO soil classification system. Skjern Meadows is covered by various international conventions. For example, it is categorised as "Wetland of International Importance" according to the Ramsar Convention (http://www.ramsar.org).

The vegetation on the former cultivated fields changed rapidly as a consequence of the restoration and the changed hydrological conditions (Pedersen et al., 2007). By 2003, the coverage of the wetland by the soft-rush (Juncus effusus) meadow community had increased from 2 to $26 \%$, making it the most abundant plant community, followed by the reedcanary grass (Phalaris arundinacea) community covering $21 \%$ of the land surface and the perennial ryegrass (Lolium perenne) / white clover (Trifolium repens) community with a coverage of $13 \%$ (Andersen et al., 2005; Pedersen et al., 2007).

The vegetation height is limited by both grazing and hay making. These activities also prevent the development of the meadows into woodland. The vegetation at our site was cut for hay production on 29 June 2009 and on 8 August 2011. The total annual duration of grazing by cattle ranged from three weeks in 2009 to about four months in 2010 (see Figs. 3 and 4). The numbers of livestock varied between 2 bulls (1524 months old) per hectare in 2009 and 4.5 bulls per hectare in the other two years, with the size of the herd being 45 and about 110 , respectively.

\subsection{Instrumentation}

The atmospheric fluxes of $\mathrm{CO}_{2}$ and $\mathrm{CH}_{4}$ were determined with the eddy covariance technique. The instrument mast is located at $55^{\circ} 54^{\prime} 46^{\prime \prime} \mathrm{N}$ and $8^{\circ} 24^{\prime} 17^{\prime \prime} \mathrm{E}$, at an elevation of $2 \mathrm{~m}$ above sea level. Due to legal access restrictions arising from the protected status of Skjern Meadows, the mast was positioned in a $3 \mathrm{~m}$ high hedgerow on a shallow earth bank close to a small gravel road (see Herbst et al., 2011a, for further details). A sonic anemometer (R3-50, Gill Instruments Ltd., Lymington, UK) was installed at the top of the mast at a measurement height of $7 \mathrm{~m}$ above the wetland surface. The relatively large measurement height was chosen in order to minimize the influence of the hedgerow on the turbulence. The $\mathrm{CO}_{2}$ concentration in the air was measured with an open-path infrared gas analyser (LI-7500, LI-COR Inc., Lincoln, NE, USA) mounted close to the sonic anemometer, and the mole fraction of $\mathrm{CH}_{4}$ in the air was determined by means of a gas analyser DLT-100 (Los Gatos Research Inc., Mountain View, CA, USA) based on off-axis integrated cavity output spectroscopy. The analyser was placed in a hut 
near the mast and was connected to the measurement point near the sonic anemometer through a $10.65 \mathrm{~m}$ long tube having an inner diameter of $6 \mathrm{~mm}$. A vacuum pump (XDS35i, Edwards, Sanborn, NY, USA) dragged the air into the DLT100 measurement cell at a pumping speed of $229 \mathrm{~L} \mathrm{~min}^{-1}$ when referring to cell pressure, ensuring a fully turbulent flow with a Reynolds number of 8200 and resulting in an average cell pressure of $16 \mathrm{kPa}$. The response time was $0.14 \mathrm{~s}$ and the cut-off frequency was $1.1 \mathrm{~Hz}$ (Herbst et al., 2011a). The $\mathrm{H}_{2} \mathrm{O}$ concentration necessary for the Webb correction was not measured inside the DLT-100, but in the air close to the tube inlet of the DLT-100 by means of a closed-path infrared gas analyser (LI-7000, LI-COR Inc., Lincoln, NE, USA). This instrument has not been available for the study since 2010, and the $\mathrm{H}_{2} \mathrm{O}$ concentration from the LI-7500 was used instead to calculate the latent heat flux. It was on average $20 \%$ higher than that derived from the LI-7000, however such a deviation has only a small effect on the size of the Webb correction (Herbst et al., 2011a). All measurements were taken at a nominal frequency of $10 \mathrm{~Hz}$.

Auxiliary data collected near the instrument mast comprised soil temperatures at three depths, air temperature and humidity as well as up- and downward short- and longwave radiation. All data (fast eddy covariance data plus half hourly auxiliary data) were logged on a CR3000 data logger (Campbell Scientific Ltd., Shepshed, Loughborough, UK). Since all data were acquired and synchronised digitally, potential noise due to digital to analogue transformations (Eugster and Plüss, 2010) was avoided. The synchronisation of the sonic anemometer and the Licor gas analysers was achieved through polling the instruments by the data logger, however the DLT-100 sent its data independently at an average frequency of about $9.4 \mathrm{~Hz}$. As a consequence, about every 20th record of the $10 \mathrm{~Hz}$ sonic data had no matching $\mathrm{CH}_{4}$ record and was thus discarded for the $\mathrm{CH}_{4}$ flux calculations. Every night the raw data were transferred automatically from the logger to an on-site server computer and further to Copenhagen University.

Volumetric soil moisture content at a slightly elevated location near the instrument mast was measured hourly from April 2009 to September 2011 by means of the TDR method. The automated TDR measurements (Schelde et al., 1998) were made at five different depths from 0.2 to $1 \mathrm{~m}$ below the soil surface, using 20 -cm-long probes.

A web camera (TN-TV-IP400, Trendnet.dk, Denmark) installed at $5 \mathrm{~m}$ height on the instrument mast and pointing into the main wind direction (west) has been in operation since the early spring of 2009. It takes one picture every day at 11:00 local time, which documents the visual development of the vegetation and the approximate height of the water table as indicated by water pools in certain places. For more details about the instrumentation, including instrument maintenance and performance, we refer to Herbst et al. (2011a) and Ringgaard et al. (2011).

\subsection{Flux calculations and gap filling}

The turbulent fluxes of $\mathrm{CO}_{2}$ and $\mathrm{CH}_{4}$ were calculated from the covariances of the vertical wind component and the respective gas concentrations by means of the "Alteddy" software, version 3.5 (Alterra, University of Wageningen, The Netherlands). A dilution correction (Webb et al., 1980) was performed for both the $\mathrm{CO}_{2}$ and the $\mathrm{CH}_{4}$ fluxes, and the $\mathrm{CO}_{2}$ fluxes were additionally corrected for errors due to surface heating of the LI-7500 sensor head using the standard parameterisation of Burba et al. (2008). All fluxes were corrected for errors caused by the tilt of the anemometer relative to the mean streamline coordinate system by means of the "planar fit" method (Wilczak et al., 2001).

Following a quality control of the flux data according to Foken et al. (2004), only data having one of the three best quality flags were accepted for further analysis. All other data, along with a few spikes undetected by Foken's method, were rejected and, in case of $\mathrm{CO}_{2}$, replaced by values estimated by the standard gap-filling method used by the FLUXNET community, which is available as an online tool at http://www.bgc-jena.mpg.de/_MDIwork/eddyproc/ (Reichstein et al., 2005). This affected a bit more than one third of all half-hourly $\mathrm{CO}_{2}$ flux data. For methane, daily averages were calculated, and gaps in the daily data, arising from situations when less than $12 \mathrm{~h}$ of good data were available for a particular day, were filled with estimates based on soil temperature and season, using response functions of the form

$F_{\mathrm{CH}_{4}}=A \cdot e^{B \cdot t}$,

where $A$ and $B$ are empirical, site-specific parameters and $t$ is soil temperature at $20 \mathrm{~cm}$ depth in ${ }^{\circ} \mathrm{C}$ (Herbst et al., 2011a). This function explained $65 \%$ of the variance during periods with high water table but only $16 \%$ during periods with low water table. About $12 \%$ of all daily $\mathrm{CH}_{4}$ fluxes had to be estimated in this way.

Since the total atmospheric fluxes of $\mathrm{CO}_{2}$ and $\mathrm{CH}_{4}$ consist of contributions from the turbulent fluxes measured with eddy covariance and the flux into storage in the air column below the sonic anemometer, the changes in storage were estimated from the changes in $\mathrm{CO}_{2}$ and $\mathrm{CH}_{4}$ mole fraction over the respective time interval and added to the turbulent fluxes. Due to the location of the site in a windy region on the Danish west coast, the storage fluxes were normally very small. Their half-hourly absolute values averaged $0.5 \mu \mathrm{mol} \mathrm{m}^{-2} \mathrm{~s}^{-1} \mathrm{CO}_{2}$ and $3 \mathrm{nmol} \mathrm{m}^{-2} \mathrm{~s}^{-1} \mathrm{CH}_{4}$, and on a daily basis they were practically zero.

According to the GWP definition used in this study, the radiative forcing of $1 \mathrm{~g} \mathrm{CH}_{4}$ is equivalent to that of $25 \mathrm{~g} \mathrm{CO}_{2}$ (IPCC, 2007). The $\mathrm{CH}_{4}$ fluxes measured at Skjern Meadows (in $\mathrm{g} \mathrm{m}^{-2}$ ) were thus multiplied by 25 and added to the measured $\mathrm{CO}_{2}$ flux to give the total GHG budget. Another important greenhouse gas, nitrous oxide $\left(\mathrm{N}_{2} \mathrm{O}\right)$, was not measured because only small fluxes were expected (see Sect. 4.2). Thus $\mathrm{N}_{2} \mathrm{O}$ was neglected in the total GHG balance. 
Table 1. Meteorological conditions during the 3 full years of investigation.

\begin{tabular}{lrrrrrrr}
\hline Time & \multicolumn{3}{c}{ Mean temperature $\left[{ }^{\circ} \mathrm{C}\right]$} & & \multicolumn{3}{c}{ Total precipitation $[\mathrm{mm}]$} \\
\cline { 2 - 3 } \cline { 7 - 8 } & 2009 & 2010 & 2011 & & 2009 & 2010 & 2011 \\
\hline Jan-Mar & 2.0 & -1.1 & 1.3 & & 157 & 99 & 142 \\
Apr-Jun & 11.4 & 9.7 & 11.8 & & 101 & 104 & 135 \\
Jul-Sep & 15.6 & 15.3 & 15.1 & & 236 & 279 & 338 \\
Oct-Dec & 5.2 & 2.3 & 6.9 & & 305 & 229 & 225 \\
\hline Total & 8.6 & 6.6 & 8.8 & & 799 & 711 & 840 \\
\hline
\end{tabular}

The observed net $\mathrm{CO}_{2}$ fluxes (NEE) were separated into day and night time and related to incoming solar radiation $\left(R_{G}\right)$ and air temperature $(t)$ in ${ }^{\circ} \mathrm{C}$, respectively. The nonlinear regressions used were

$\mathrm{NEE}_{\text {night }}=R_{10} \cdot e^{308.6 \cdot\left(\frac{1}{56}-\frac{1}{t+46}\right)}$

for the nighttime data where $R_{10}$ is the respiration rate at $10^{\circ} \mathrm{C}$ (Lloyd and Taylor, 1994) and

$\mathrm{NEE}_{\text {day }}=\frac{a \cdot b \cdot R_{G}}{a \cdot R_{G}+b}+c$

for the day-time data (Ruimy et al., 1995; Frolking et al., 1998), where $a$ corresponds to the initial slope of the curve, $b$ is the maximum net $\mathrm{CO}_{2}$ uptake rate, and $c$ is the net $\mathrm{CO}_{2}$ emission when the radiation is zero.

The curve fitting was performed with SigmaPlot 9.0 (SSI, San Jose, CA, USA). Its fitting routine is based on the Marquardt-Levenberg algorithm (Marquardt, 1963) which uses least squares analysis.

\section{Results}

\subsection{Climatic conditions and annual atmospheric GHG exchange}

The seasonal and annual average temperatures were fairly similar in 2009 and 2011, except for the warmer autumn in 2011 (Table 1). In contrast, 2010 was more than $2{ }^{\circ} \mathrm{C}$ colder than the other years. This was mainly due to an unusually cold winter and spring, whereas the mean temperature from July to September did not differ from the other years. Fall was again colder in 2010 when the 3-month average temperature was almost $5{ }^{\circ} \mathrm{C}$ lower than in 2011. 2010 was also drier than 2009 and 2011, with a similar seasonal distribution of the precipitation for all three years (Table 1). There was always more precipitation in the second half of the year than in the first half, and April was the driest month in all years (data not shown).

The daily totals of the $\mathrm{CO}_{2}$ and $\mathrm{CH}_{4}$ exchange between the wetland and the atmosphere are shown in Fig. 1 for the
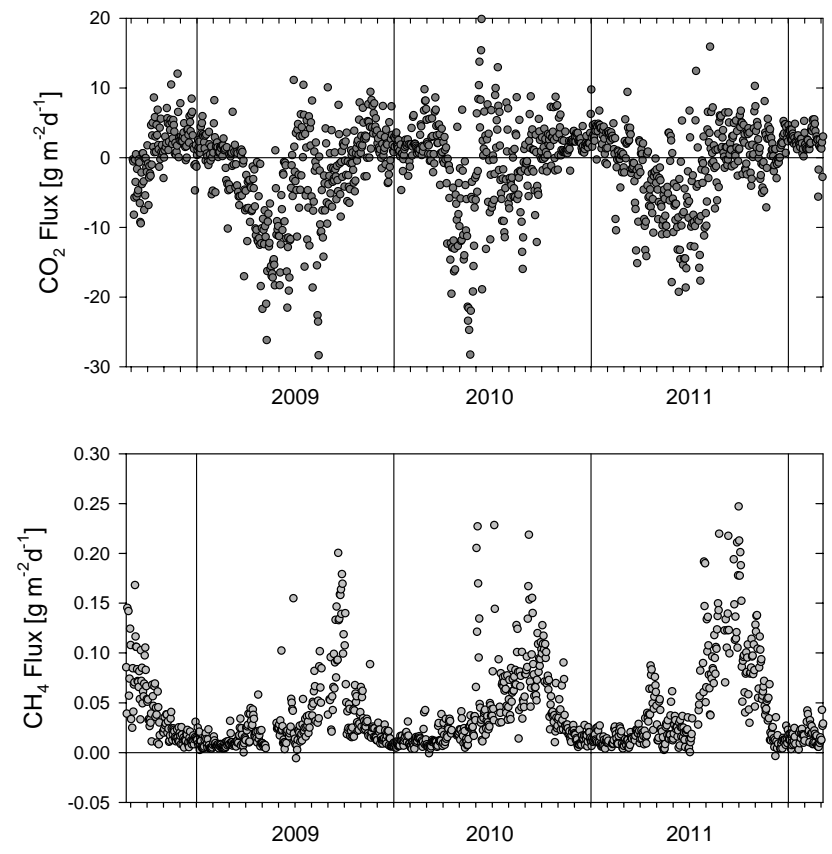

Fig. 1. Daily atmospheric fluxes of $\mathrm{CO}_{2}$ (upper panel) and $\mathrm{CH}_{4}$ (lower panel) over the first $3.5 \mathrm{yr}$ of measurements at Skjern Meadows. Upward fluxes are defined as positive.

first $3.5 \mathrm{yr}$ of the observations. For the $\mathrm{CO}_{2}$ fluxes, the expected general tendency towards negative (downward) fluxes in the summer and positive (upward) fluxes in the winter is evident, however positive daily totals were observed for several days in the summer, too. In contrast to $\mathrm{CO}_{2}$, the $\mathrm{CH}_{4}$ exchange was almost always directed upwards, and in all years the largest $\mathrm{CH}_{4}$ emissions occurred in late summer and early autumn (Fig. 1). Apparently, the maximum daily emission rates have increased from year to year since the start of the measurements in the late summer of 2008.

After converting the daily $\mathrm{CH}_{4}$ fluxes into $\mathrm{CO}_{2}$ equivalents, they were balanced against the daily $\mathrm{CO}_{2}$ fluxes, and the total greenhouse gas exchange (with respect to the global warming potential of the two gases) was cumulated over an entire calendar year. The interannual comparison of the cumulative GHG budget (Fig. 2) revealed marked differences between the three years. Whilst Skjern Meadows was a substantial GHG sink in 2009, it turned into a moderate source in 2010 and became about neutral in 2011, considering the typical uncertainty of the flux totals (see Table 2 and Sect. 4.1). The net GHG uptake started late in the cold and dry year (2010) compared to the other two years. In 2010 the period of a net GHG uptake had already ended in late May, whereas it otherwise lasted until early August (2011) or even late August (2009).

Regardless of the differences in GHG flux totals, the site always remained a carbon sink (Table 2). Table 2 also demonstrates that the interannual variability of the $\mathrm{CO}_{2}$ flux so far has been larger than the variability in $\mathrm{CH}_{4}$ emissions. 
Table 2. Annual atmospheric greenhouse gas budget for the 3 full years of measurements. Upward fluxes are defined as positive.

\begin{tabular}{|c|c|c|c|c|c|c|c|}
\hline \multirow[b]{2}{*}{ Year } & \multicolumn{2}{|c|}{$\mathrm{CO}_{2}$ flux } & \multicolumn{3}{|c|}{$\mathrm{CH}_{4}$ flux } & \multirow{2}{*}{$\begin{array}{l}\text { GHG budget } \\
\mathrm{g} \mathrm{CO}_{2} \text { eq m }^{-2}\end{array}$} & \multirow{2}{*}{$\begin{array}{l}\text { Carbon budget } \\
\mathrm{g} \mathrm{C} \mathrm{m}^{-2}\end{array}$} \\
\hline & $\mathrm{g} \mathrm{m}^{-2}$ & $\mathrm{gCm}^{-2}$ & $\mathrm{~g} \mathrm{~m}^{-2}$ & $\mathrm{gC} \mathrm{m}^{-2}$ & $\mathrm{~g} \mathrm{CO}_{2} \mathrm{eq} \mathrm{m}^{-2}$ & & \\
\hline 2009 & $-983 \pm 147$ & $-268 \pm 40$ & $11 \pm 2$ & $9 \pm 1$ & $284 \pm 43$ & $-700 \pm 190$ & $-259 \pm 41$ \\
\hline 2010 & $-195 \pm 29$ & $-53 \pm 8$ & $14 \pm 2$ & $11 \pm 2$ & $359 \pm 54$ & $163 \pm 83$ & $-42 \pm 10$ \\
\hline 2011 & $-387 \pm 58$ & $-105 \pm 16$ & $17 \pm 3$ & $13 \pm 2$ & $432 \pm 65$ & $45 \pm 123$ & $-92 \pm 18$ \\
\hline
\end{tabular}

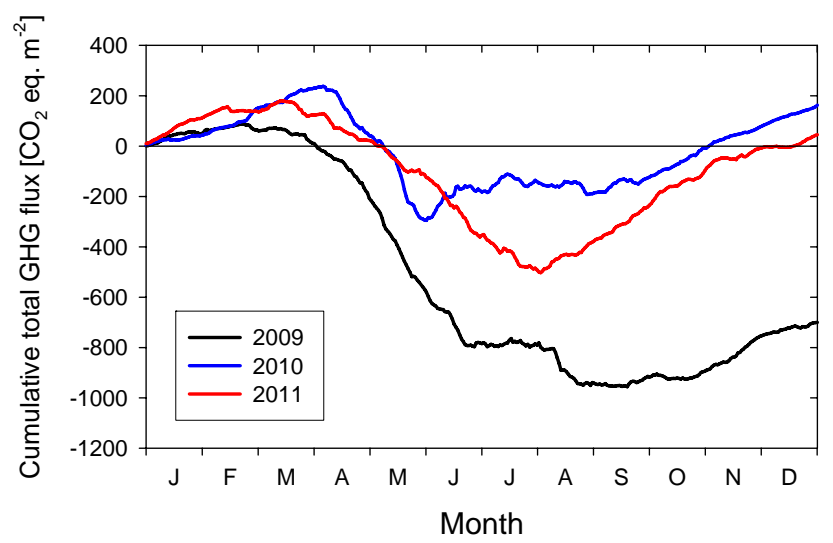

Fig. 2. The total cumulative greenhouse gas fluxes for the three full calendar years of measurements, including both $\mathrm{CO}_{2}$ and $\mathrm{CH}_{4}$ in $\mathrm{CO}_{2}$ equivalents. Upward fluxes are defined as positive.

The highest and lowest annual totals differed by a factor of five for $\mathrm{CO}_{2}$ but only by a factor of about one and a half for $\mathrm{CH}_{4}$. In the following paragraphs the annual budgets and the temporal variability in relation to various environmental factors will be treated separately for the two greenhouse gases.

\subsection{Temporal variability of $\mathrm{CO}_{2}$ fluxes}

The large differences between the individual annual courses of the $\mathrm{CO}_{2}$ flux were related to specific management and weather events (Fig. 3). Due to the similar seasonal rainfall distribution, the periods with low and high water tables hardly differed between the years. However, the duration of the snow cover varied considerably, with 2010 having an exceptionally long period of snow cover, which, according to Denmark's Meteorological Institute, was indeed the longest since the start of their recordings more than a hundred years ago. This situation is mirrored in the $\mathrm{CO}_{2}$ flux, especially if early 2009 is compared with early 2010 . The turning point of the cumulative net flux was reached more than a month later in 2010 rather than in 2009 due to the delayed start of the growing season (Fig. 3).

The further seasonal course and its interannual differences correlated with management activities rather than weather events. An attempt to quantify the relative importance of these control factors is presented in Sect. 4.2, however some key effects are already apparent from Fig. 3. The long period

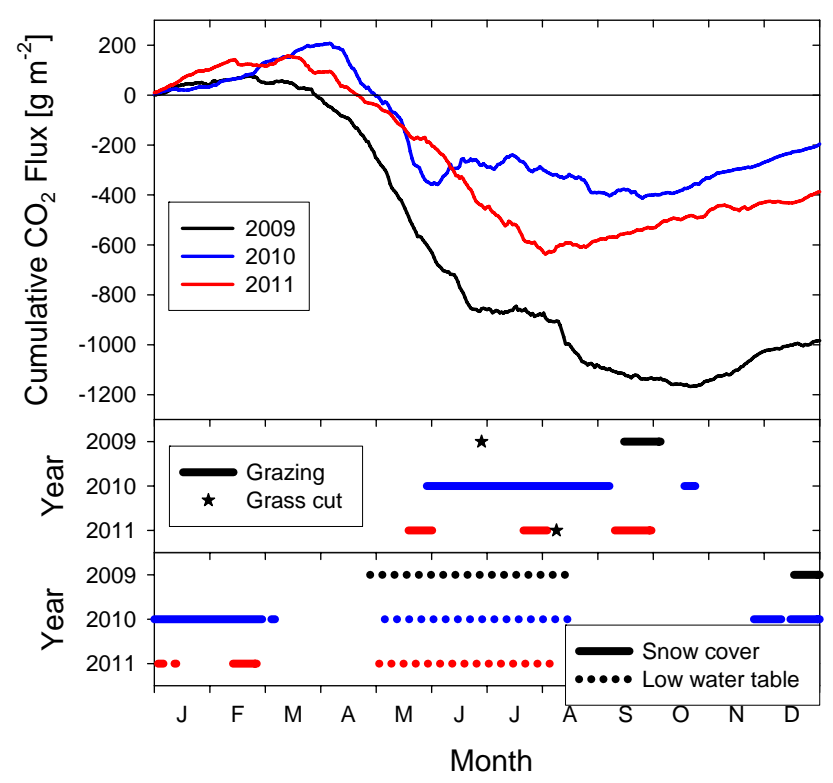

Fig. 3. Cumulative $\mathrm{CO}_{2}$ fluxes (upper panel) shown together with management activities (middle panel), snow cover duration and water table height (lower panel). See text for the definition of "low" and "high" water table.

of grazing in 2010 brought the net $\mathrm{CO}_{2}$ uptake to a halt already in late spring, whereas the net uptake continued into August in 2011 and well into autumn in 2009. The re-growth following the late grass cutting in 2011 could not compensate any more for the respirative $\mathrm{CO}_{2}$ emissions, whilst the early cut in 2009 enabled a full recovery of the vegetation in terms of its leaf area index (Herbst et al., 2011b) and thus a continued net $\mathrm{CO}_{2}$ uptake over the rest of the growing season (Fig. 3).

\subsection{Temporal variability of $\mathrm{CH}_{4}$ fluxes}

Most of the steepest parts of the cumulative annual $\mathrm{CH}_{4}$ flux curves coincided with periods of grazing (Fig. 4). The continuous grazing in the summer of 2010, for example, caused considerable $\mathrm{CH}_{4}$ emissions even at a time when the low water table must have inhibited direct $\mathrm{CH}_{4}$ emissions from the soil due to oxidation of $\mathrm{CH}_{4}$ in the aerated top soil. This indicates that $\mathrm{CH}_{4}$ emissions from rumination must have contributed to the measured flux. Despite a reduced grazing 


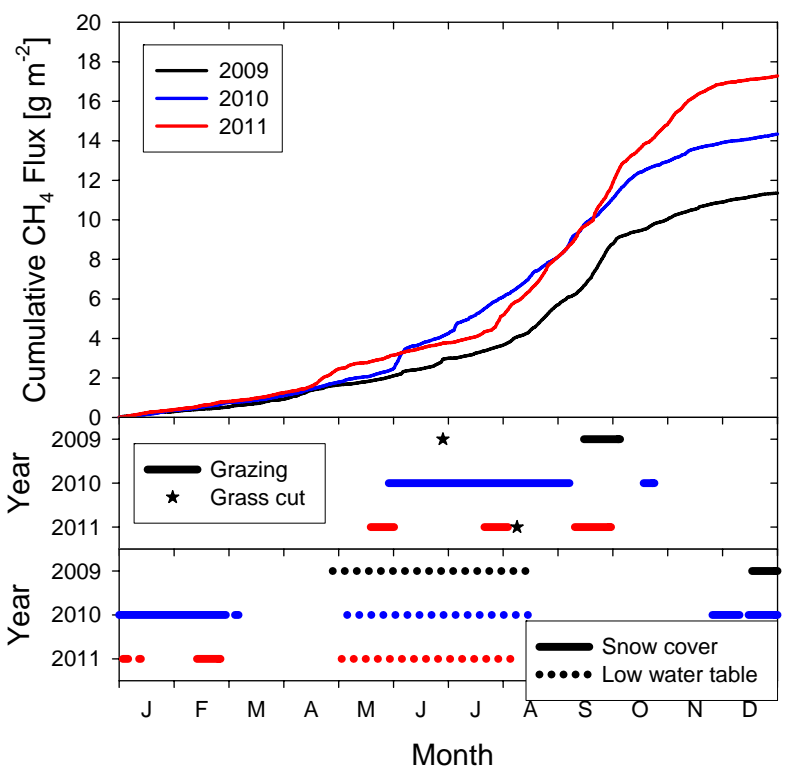

Fig. 4. Same as Fig. 3 but for $\mathrm{CH}_{4}$ instead of $\mathrm{CO}_{2}$.

intensity in 2011, the total annual $\mathrm{CH}_{4}$ efflux was even higher than in 2010, not least because the emissions rates in the autumn, after the end of the grazing period, were higher than in both other years. This means that, during the observation period, the annual $\mathrm{CH}_{4}$ emissions have so far increased from year to year (Table 2 and Fig. 4). The varying timing and duration of the snow cover did not have any influence on the $\mathrm{CH}_{4}$ emissions rates, according to Fig. 4.

The interaction of water table height, soil temperature and presence of grazing cattle in driving the $\mathrm{CH}_{4}$ emissions from Skjern Meadows is illustrated in Fig. 5. The respective symbols indicate a clear functional switch between situations with low and high water table and a strong exponential temperature influence for periods with high water table. For days with grazing, daily $\mathrm{CH}_{4}$ fluxes are often at the higher end of the range of fluxes for the respective temperatures (under both dry and wet soil conditions). To separate grazing effects from meteorological forcing, days with grazing were removed from the data shown in Fig. 5, the remaining data from all years were pooled and two new temperature response functions were fitted for high and low WT, respectively (Table 3 ). The resulting model was used to predict $\mathrm{CH}_{4}$ fluxes in the absence of grazing for the entire 3-yrperiod. Plotting the differences between the measured and the predicted fluxes against time revealed that, during grazing, the deviation from the predicted fluxes was predominantly positive (Fig. 6). The total annual deviation amounted to $1.0 \mathrm{~g} \mathrm{~m}^{-2}$ in the first year 2009 and to $2.7 \mathrm{~g} \mathrm{~m}^{-2}$ in each of the following years.

Another potential control factor for the $\mathrm{CH}_{4}$ emissions from the wetland is visible in Fig. 6 where the arrows and ovals indicate periods when the measured fluxes systematically exceeded the predictions. It cannot be excluded that
Table 3. Results from the curve fitting for the $\mathrm{CH}_{4}$ flux versus soil temperature plots shown in Fig. 7, using Eq. (1).

\begin{tabular}{lll}
\hline & High water table & Low water table \\
\hline 2009 & & (D 119-D 227) \\
$A\left[\mathrm{~g} \mathrm{~m}^{-2} \mathrm{~d}^{-1}\right] \pm \mathrm{SE}$ & $0.0086 \pm 0.0013$ & $0.0034 \pm 0.0031$ \\
$B\left[{ }^{\circ} \mathrm{C}^{-1}\right] \pm \mathrm{SE}$ & $0.151 \pm 0.011$ & $0.129 \pm 0.056$ \\
\hline 2010 & & (D 127-D 227) \\
$A\left[\mathrm{~g} \mathrm{~m}^{-2} \mathrm{~d}^{-1}\right] \pm \mathrm{SE}$ & $0.0129 \pm 0.0014$ & $0.0109 \pm 0.0060$ \\
$B\left[{ }^{\circ} \mathrm{C}^{-1}\right] \pm \mathrm{SE}$ & $0.128 \pm 0.008$ & $0.104 \pm 0.034$ \\
\hline 2011 & & $(\mathrm{D} 124-\mathrm{D} 222)$ \\
$A\left[\mathrm{~g} \mathrm{~m}^{-2} \mathrm{~d}^{-1}\right] \pm \mathrm{SE}$ & $0.0124 \pm 0.0017$ & $(0 \pm 0)$ \\
$B\left[{ }^{\circ} \mathrm{C}^{-1}\right] \pm \mathrm{SE}$ & $0.162 \pm 0.010$ & $(0.576 \pm 0.097)$ \\
\hline All years excluding periods with grazing & \\
$A\left[\mathrm{~g} \mathrm{~m}^{-2} \mathrm{~d}^{-1}\right] \pm \mathrm{SE}$ & $0.0106 \pm 0.0048$ & $0.0049 \pm 0.0022$ \\
$B\left[{ }^{\circ} \mathrm{C}^{-1}\right] \pm \mathrm{SE}$ & $0.149 \pm 0.006$ & $0.112 \pm 0.029$ \\
\hline
\end{tabular}

surplus $\mathrm{CH}_{4}$ emissions were triggered by the first complete wetting of the top soil after the dry summer period in the slightly more elevated parts of the wetland and that this effect in 2009 was overshadowed by the simultaneous grazing.

When the water table was high and the soil temperature exceeded a threshold of about $9^{\circ} \mathrm{C}$, the $\mathrm{CH}_{4}$ emission rates appeared to increase from year to year, even when no cattle were present in the source area of the flux measurements (Fig. 5). Possible reasons for this observation are discussed in Sect. 4.4. To test the significance of any differences in the temperature response of the $\mathrm{CH}_{4}$ flux between years and under different WT and management situations, the data set was split further into high WT, low WT, and days with grazing for each year. The $\mathrm{CH}_{4}$ flux data were log-transformed and a one-way analysis of covariance (ANCOVA) was conducted (Table 4).

Most of the slopes of the temperature responses for high WT, low WT and grazing (corresponding to the curvature of the lines in Fig. 5) were statistically similar. In contrast, the adjusted means of most of the groups differed significantly. For example, the temperature-adjusted $\mathrm{CH}_{4}$ emissions on days with high WT but without grazing were significantly higher in 2011 compared to 2009, with 2010 showing intermediate values which were not different from either 2009 or 2011. Within the years, most of the differences between treatments were significant, too (Table 4). When, like in 2009, most of the grazing took place under high WT, days with grazing had higher $\mathrm{CH}_{4}$ fluxes than days with high WT but without grazing which again had higher fluxes than days with low WT. In 2010 and 2011 grazing mainly took place when the WT was low. In both years the temperatureadjusted fluxes during low WT without grazing were significantly lower than during the rest of the year. Whilst fluxes during high WT without grazing were higher than during low WT with grazing in 2010, these two treatments were statistically similar in 2011 . 


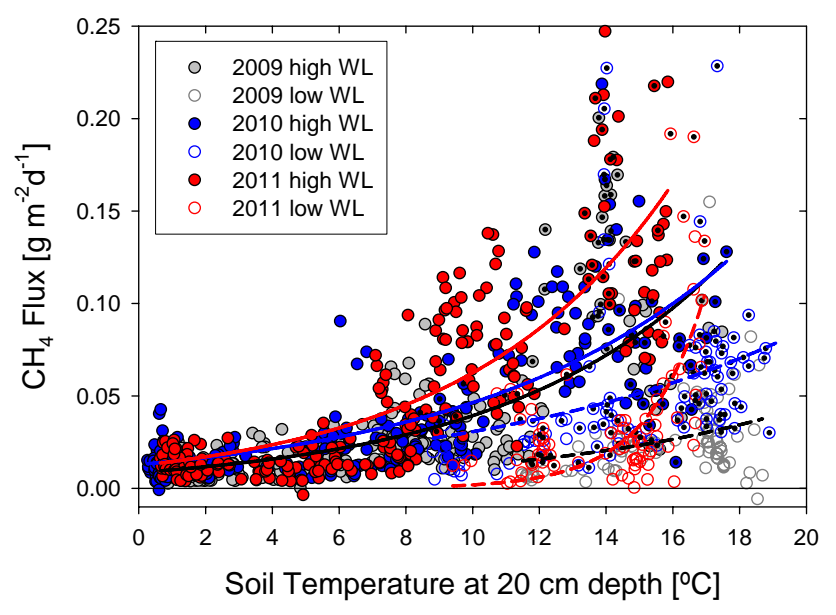

Fig. 5. Daily $\mathrm{CH}_{4}$ fluxes observed over three years in relation to soil temperature at $20 \mathrm{~cm}$ depth. Different symbols indicate periods with low and high water table and periods with (black dots) and without grazing, respectively.

Table 4. ANCOVA results for the log-transformed temperature response of the $\mathrm{CH}_{4}$ flux for different years and treatments. Combinations of year and treatment without a common letter are statistically different $(P<0.05)$.

\begin{tabular}{lrrr}
\hline Slopes & High WT & Low WT & Grazing \\
\hline 2009 & $0.137^{\mathrm{a}}$ & $0.184^{\mathrm{ab}}$ & $0.241^{\mathrm{abcd}}$ \\
2010 & $0.154^{\mathrm{ad}}$ & $0.204^{\mathrm{abde}}$ & $0.051^{\mathrm{df}}$ \\
2011 & $0.188^{\mathrm{b}}$ & $0.151^{\mathrm{abf}}$ & $0.342^{\mathrm{ce}}$ \\
\hline Adjusted Means & & & \\
\hline 2009 & $3.13^{\mathrm{af}}$ & $2.05^{\mathrm{c}}$ & $4.14^{\mathrm{be}}$ \\
2010 & $3.52^{\mathrm{abg}}$ & $2.60^{\mathrm{d}}$ & $3.07^{\mathrm{f}}$ \\
2011 & $3.60^{\mathrm{bg}}$ & $2.20^{\mathrm{cd}}$ & $3.50^{\mathrm{g}}$ \\
\hline
\end{tabular}

\section{Discussion}

\subsection{Accuracy and source area variability}

The typical uncertainty for long-term eddy covariance measurements of $\mathrm{CO}_{2}$ and $\mathrm{CH}_{4}$ has often been estimated to be about $15 \%$ of the total flux when expressed as a relative error (e.g. Schrier-Uijl et al., 2010; Herbst et al., 2011b). This estimate was used in this study, too. Potential sources of uncertainty are sensor resolution and calibration errors, as well as flux corrections due to, for example, frequency losses and density fluctuations. According to the specifications provided by the manufacturers and to sensitivity tests for the flux corrections this error did not exceed $10 \%$. For uncertainties in the gap filling an additional error margin of $5 \%$ was added, resulting in an overall uncertainty of $15 \%$. According to Kroon et al. (2010) the uncertainty in annual eddy covariance $\mathrm{CH}_{4}$ fluxes is even smaller than $10 \%$ if the data coverage exceeds $80 \%$ and a multivariate regression is

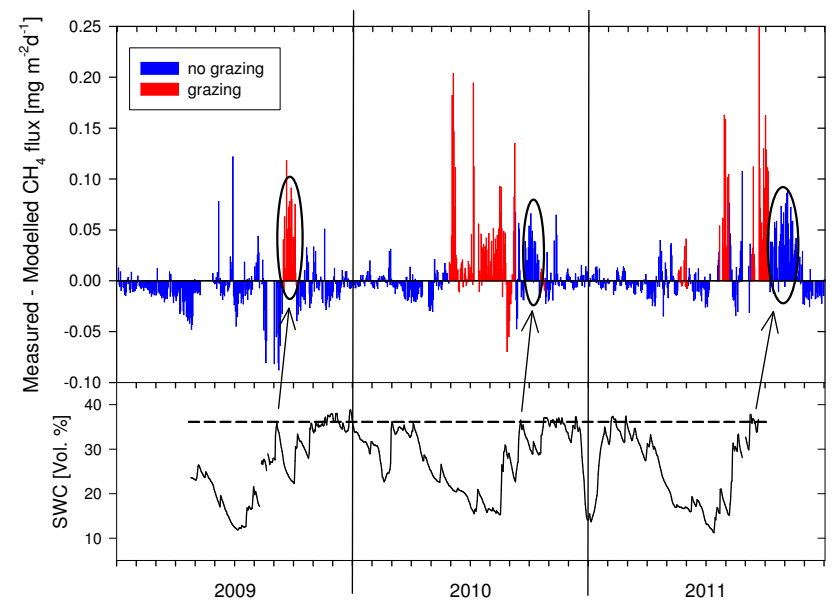

Fig. 6. Upper panel: deviation of measured daily $\mathrm{CH}_{4}$ fluxes from a simple model based on exponential temperature functions for two different water level (WL) classes. The functions were fitted to the entire $3 \mathrm{yr}$ data series excluding the periods with grazing (Table 3). For high WL the function was $F_{\mathrm{CH}_{4} \text {, hw }}=0.0106 \cdot e^{0.149^{T}}$ $\left(R^{2}=0.54\right)$ and for low WL it was $F_{\mathrm{CH}_{4}, \mathrm{lw}}=0.0049 \cdot e^{0.112^{T}}$ $\left(R^{2}=0.10\right)$ where $T$ is the soil temperature $\left[{ }^{\circ} \mathrm{C}\right]$ at $20 \mathrm{~cm}$ depth. Lower panel: time course of volumetric soil water content at $20 \mathrm{~cm}$ depth in a slightly elevated location near the instrument mast. The broken line indicates the estimated field capacity (FC) of the soil and the arrows indicate the time in late summer when FC was reached for the first time in the respective growing season.

used for gap filling. However, as the named errors can occur independently for $\mathrm{CO}_{2}$ and $\mathrm{CH}_{4}$ fluxes (being based on data from different gas analysers and subjected to different control factors), the estimated absolute errors for the two gas fluxes were added to estimate the uncertainty of the total annual GHG budget (Table 2). As a result, it can be reasonably assumed that the statements about Skjern Meadows being a GHG sink in 2009 and a GHG source in 2010 are certain. In contrast, the small net GHG emission estimated for 2011 is well within the uncertainty limit of the method used, which means that the 2011 budget was too close to zero to define it with certainty as a sink or a source.

The main focus in this paper was on annual budgets, because these are less sensitive than shorter time frames to additional uncertainties caused by changes in the source area of the observed fluxes (Forbrich et al., 2011; Baldocchi et al., 2012). Methane fluxes in particular are known to be spatially highly variable, and thus changes in the source area due to changes in wind direction or atmospheric stability can dominate the observed variations in the fluxes and mask their environmental control over time scales of hours to days (Forbrich et al., 2011). Herbst et al. (2011a) presented evidence that this plays a role at Skjern Meadows, too, not only with respect to flux peaks coming from the cattle but also regarding the background fluxes that depended on the prevailing wind direction. 


\subsection{Atmospheric fluxes and the total GHG budget}

In order to avoid any misinterpretations of this study it should be pointed out that only the atmospheric budget was considered here. A total field budget of greenhouse gases would have to include import and export of $\mathrm{CO}_{2}$ (for example through manure application and hay making, respectively) as well as a potential leaching of $\mathrm{CO}_{2}$ and $\mathrm{CH}_{4}$ to the river and the weight gain of the animals (Allard et al., 2007; Soussana et al., 2007). A true farm-scale GHG budget would have to cover even more processes with respect to meat production, transport etc. (Byrne et al., 2007). None of the named processes was subject of this study, however for the field budget this did not play a major role. Leaching and animal weight gain can be neglected in the bigger picture (Allard et al., 2007), and there was no import of $\mathrm{CO}_{2}$. The only modification in order to arrive at a field budget would be to calculate the amount of biomass having been removed after the two cuttings in 2009 and 2011.

The last uncertainty when assessing total GHG budgets is the potential role of GHGs other than $\mathrm{CH}_{4}$ and $\mathrm{CO}_{2}$. The main suspect for a managed grassland would be nitrous oxide $\left(\mathrm{N}_{2} \mathrm{O}\right)$, which is mostly emitted at medium soil water content but reduced in wet soil (van Beek et al., 2011). At a nearby site in the Skjern river valley, however, outside the restoration area, Petersen et al. (2012) observed considerable $\mathrm{N}_{2} \mathrm{O}$ emissions of $1.2 \mathrm{~g} \mathrm{~m}^{-2} \mathrm{a}^{-1}$ (or $358 \mathrm{~g} \mathrm{~m}^{-2} \mathrm{a}^{-1}$ in terms of $\mathrm{CO}_{2}$ equivalents) from grassland on decomposing peat. In a seasonally wet grassland, however, $\mathrm{N}_{2} \mathrm{O}$ accounted for only $1 \%$ of the total atmospheric GHG flux when expressed as $\mathrm{CO}_{2}$ equivalents (Gleason et al., 2009), and this percentage becomes higher only if the site is fertilized (Kroon et al., 2010), which is not the case at Skjern Meadows. Kroon et al. (2010) concluded that the $\mathrm{N}_{2} \mathrm{O}$ flux from rewetted and unfertilized former agricultural land is negligible, and the same conclusion was reached in the synthesis paper by Maljanen et al. (2010). Therefore we consider it as unlikely that Skjern Meadows could have emitted significant amounts of $\mathrm{N}_{2} \mathrm{O}$ during this study. In summary, the atmospheric GHG budgets presented here are nearly equivalent to a complete field budget, apart from the biomass removed through hay making.

\subsection{Impacts of climate and management on $\mathrm{CO}_{2}$ fluxes}

Theoretically, wet grasslands can be expected to function as $\mathrm{CO}_{2}$ sinks as they accumulate a major part of the carbon fixed through photosynthesis as peat. However, the exact budget will depend on the vegetation and its canopy photosynthetic capacity and can be difficult to predict if a wetland is not yet in equilibrium, for example following restoration (Drösler et al., 2008). It is known that site management plays a role, too, and Jacobs et al. (2007) reported a rather unexpected average annual $\mathrm{CO}_{2}$ release of $220 \pm 90 \mathrm{~g} \mathrm{C} \mathrm{m}^{-2}$ for four Dutch grasslands on organic soils having a relatively high water table and including both managed and unmanaged sites. In contrast, Hendriks et al. (2007) observed a consistent net $\mathrm{CO}_{2}$ uptake between 232 and $446 \mathrm{~g} \mathrm{C} \mathrm{m}^{-2} \mathrm{a}^{-1}$ for a restored wet grassland with neither grazing nor cutting. We are not aware of any other long-term study of $\mathrm{CO}_{2}$ fluxes above grazed restored wetlands. However, looking at an example for a drained former wetland site that has not (yet) been restored, Hatala et al. (2012) determined the GHG budget of a grazed degraded peatland in California and showed that the site was a strong $\mathrm{CO}_{2}$ source emitting up to $300 \mathrm{~g} \mathrm{C} \mathrm{m}^{-2} \mathrm{a}^{-1}$ as $\mathrm{CO}_{2}$ (and additionally $3 \mathrm{~g} \mathrm{C}$ as methane). These numbers agree well with studies from Europe where grasslands on drained peat soils are always net $\mathrm{CO}_{2}$ sources because of peat decomposition, independent of the specific site management (Maljanen et al., 2010; Elsgaard et al., 2012). The rewetting of such sites can therefore always be considered as an improvement with respect to the $\mathrm{CO}_{2}$ (and $\mathrm{GHG}$ ) balance, regardless of the exact annual net $\mathrm{CO}_{2}$ flux and its variation.

Regarding the NEE of an unfertilized, grazed grassland on mineral soil Klumpp et al. (2011) reported an interannual variability by one order of magnitude (net $\mathrm{CO}_{2}$ uptake between 49 and $486 \mathrm{~g} \mathrm{C} \mathrm{m}^{-2} \mathrm{a}^{-1}$ ), with the higher net uptake rates occurring in relatively cool years. If a similar response to the annual temperature was also present in this study, it was overshadowed by other control factors, because the coolest year (2010) actually showed the lowest net $\mathrm{CO}_{2}$ uptake. The impact of the position of the water table on the $\mathrm{CO}_{2}$ fluxes remains unclear, too, not only in this study but also in the literature. Lloyd (2006) observed a linear reduction in $R_{10}$ (Eq. 1) with raising water table, which is in agreement with theory and expectations (Drösler et al., 2008). In contrast, Parmentier et al. (2009) and Elsgaard et al. (2012) reported exactly the opposite and concluded there was no influence of the water table height on ecosystem respiration. In the present study changes in the position of the water table can only have affected the seasonal course of NEE but not its interannual variability as the hydrological conditions were very similar in all $3 \mathrm{yr}$. This also means that the apparent, small effect on $R_{10}$ (Table 5) certainly cannot be ascribed to water table differences because these were confounded with seasonality during the first $3 \mathrm{yr}$ of measurements.

The only significant climatic influence on the annual net $\mathrm{CO}_{2}$ flux was the delayed start of the growing season in 2010 due to the long lasting snow cover, which produced an offset in the cumulative $\mathrm{CO}_{2}$ flux during springtime of at least $200 \mathrm{~g} \mathrm{~m}^{-2}$ (Fig. 3), corresponding to $>20 \%$ of the annual net $\mathrm{CO}_{2}$ exchange. Even without the longer grazing period and the larger number of cattle, this exceptional weather pattern would thus have reduced the annual net carbon uptake by Skjern Meadows of that year. A similar effect was observed at a subarctic site where, compared over many years, the snowmelt date had the largest influence on the annual $\mathrm{CO}_{2}$ budget (Aurela et al., 2004).

The grass cutting was the other major influence factor, as evident from Fig. 3. Looking at the critical periods in July 
Table 5. Results from the curve fitting of nighttime net $\mathrm{CO}_{2}$ fluxes against soil temperature and daytime net $\mathrm{CO}_{2}$ fluxes against incoming solar radiation. $R_{10}$ refers to Eq. (2) and $a, b$ and $c$ refer to Eq. (3).

\begin{tabular}{lll}
\hline & $\begin{array}{l}\text { July (low } \\
\text { water table) }\end{array}$ & $\begin{array}{l}\text { August (high } \\
\text { water table) }\end{array}$ \\
\hline 2009 & cut & recovered \\
$R_{10}\left[\mu \mathrm{mol} \mathrm{m}^{-2} \mathrm{~s}^{-1}\right] \pm \mathrm{SE}$ & $2.77 \pm 0.08$ & $2.87 \pm 0.07$ \\
$a[\mu \mathrm{mol} \mathrm{J}-1] \pm \mathrm{SE}$ & $-0.040 \pm 0.005$ & $-0.083 \pm 0.008$ \\
$b\left[\mu \mathrm{mol} \mathrm{m}^{-2} \mathrm{~s}^{-1}\right] \pm \mathrm{SE}$ & $-22.83 \pm 2.19$ & $-26.59 \pm 1.83$ \\
$c\left[\mu \mathrm{mol} \mathrm{m}^{-2} \mathrm{~s}^{-1}\right] \pm \mathrm{SE}$ & $4.86 \pm 0.25$ & $4.01 \pm 0.25$ \\
\hline 2010 & grazed & grazed \\
$R_{10}\left[\mu \mathrm{mol} \mathrm{m}^{-2} \mathrm{~s}-1\right] \pm \mathrm{SE}$ & $2.87 \pm 0.09$ & $2.32 \pm 0.02$ \\
$a\left[\mu \mathrm{mol} \mathrm{J}^{-1}\right] \pm \mathrm{SE}$ & $-0.094 \pm 0.009$ & $-0.072 \pm 0.010$ \\
$b\left[\mu \mathrm{mol} \mathrm{m}{ }^{-2} \mathrm{~s}^{-1}\right] \pm \mathrm{SE}$ & $-18.80 \pm 0.72$ & $-17.27 \pm 1.35$ \\
$c\left[\mu \mathrm{mol} \mathrm{m}^{-2} \mathrm{~s}^{-1}\right] \pm \mathrm{SE}$ & $6.62 \pm 0.21$ & $3.88 \pm 0.26$ \\
\hline 2011 & undisturbed & cut \\
$R_{10}\left[\mu \mathrm{mol} \mathrm{m}^{-2} \mathrm{~s}-1\right] \mathrm{SE}$ & $2.52 \pm 0.08$ & $2.10 \pm 0.15$ \\
$a\left[\mu \mathrm{mol} \mathrm{J}^{-1}\right] \pm \mathrm{SE}$ & $-0.095 \pm 0.006$ & $-0.034 \pm 0.005$ \\
$b\left[\mu \mathrm{mol} \mathrm{m}{ }^{-2} \mathrm{~s}^{-1}\right] \pm \mathrm{SE}$ & $-23.52 \pm 0.77$ & $-19.95 \pm 3.44$ \\
$c\left[\mu \mathrm{mol} \mathrm{m} \mathrm{s}^{-1}\right] \pm \mathrm{SE}$ & $5.16 \pm 0.21$ & $3.48 \pm 0.25$ \\
\hline
\end{tabular}

and August in more detail, the net $\mathrm{CO}_{2}$ flux data were separated into day and night and analysed in terms of Eqs. (3) and (2), respectively (Table 5). The variations in parameter $a$ indicate that the daytime net $\mathrm{CO}_{2}$ flux was reduced to about one half during the weeks following the cut (July 2009 and August 2011) due to the reduction in leaf area index (Herbst et al., 2011b). In contrast, differences in nighttime fluxes, representing ecosystem respiration rates, and their relation to soil temperature were small between years and treatments (parameter $R_{10}$ in Table 5). This seems plausible since the soil carbon pool, forming the substrate for respiration, does not immediately change with vegetation cover.

Grazing had a weaker effect than cutting on the daytime net $\mathrm{CO}_{2}$ flux, however it remains unclear whether, and to what extent, cattle respiration contributed to the reduction in net $\mathrm{CO}_{2}$ uptake compared to an undisturbed situation. The unexpected net $\mathrm{CO}_{2}$ emissions on some days in the summer of 2010 (Fig. 1) may well have depended on the location of the herd compared to the flux footprint (Herbst et al., 2011a; Baldocchi et al., 2012). Grazing did not create an offset (change in parameter $c$, Table 4) in the response of NEE to $R_{G}$ but rather a reduction in daytime maximum NEE (parameter $b$ ). The most likely explanation for this result is that at night (when $R_{G}=0$ ) the cattle usually congregated in an area several hundred meters away from the mast where they at most can have contributed to the "tail" of the flux footprint, and even this only for certain wind directions. Nighttime ecosystem $\mathrm{CO}_{2}$ fluxes would thus have been unaffected by cattle respiration. Due to the absence of a clear separation between background $\mathrm{CO}_{2}$ flux and cattle respiration, we did not attempt to partition the daytime $\mathrm{CO}_{2}$ flux further and to quantify the percentage of cattle respiration in the total respiration flux.

To quantify the relative importance of the various control factors, a sensitivity analysis was carried out, starting with the nighttime $\mathrm{CO}_{2}$ fluxes and their temperature dependence (Table 5). Assuming a similar response for daytime respiration, the observed range of spring temperatures ( 9.7 to $11.8^{\circ} \mathrm{C}$ ) would induce a $\mathrm{CO}_{2}$ flux difference of $8 \mathrm{~g} \mathrm{~m}^{-2}$ per month and the observed autumn temperature range (2.3 to $6.9^{\circ} \mathrm{C}$ ) would cause a flux difference of $12 \mathrm{~g} \mathrm{~m}^{-2}$ per month. This effect would result in a total change in $\mathrm{CO}_{2}$ emissions by $60 \mathrm{~g} \mathrm{~m}^{-2}$ per year (Table 6 ) if the small temperature differences in the remaining months are neglected. The observed effect of the grass cutting on the daytime $\mathrm{CO}_{2}$ uptake (Table 5) alone would correspond to a change in the $\mathrm{CO}_{2}$ flux between 60 and $80 \mathrm{~g} \mathrm{~m}^{-2}$ per month if similar solar radiation before and after the cutting is assumed. The respective reduction in $\mathrm{CO}_{2}$ uptake during grazing (see above) would equal about $45 \mathrm{~g} \mathrm{~m}^{-2}$ per month or $180 \mathrm{~g} \mathrm{~m}^{-2}$ per year for a maximum grazing duration of 4 months (Table 6). In summary, growing season length, cutting frequency and grazing intensity controlled the interannual $\mathrm{CO}_{2}$ flux variability more than changes in temperature or water table position did, and for the management effects there is evidence that changes in $\mathrm{CO}_{2}$ uptake rather than ecosystem respiration were responsible for most of the observed variability.

\subsection{Impacts of climate and management on $\mathrm{CH}_{4}$ fluxes}

Extending the sensitivity analysis to the temperature response of the $\mathrm{CH}_{4}$ flux (Table 3) revealed that the described temperature ranges, in combination with a low WT in spring and a high WT in autumn, could have caused an annual variation in the $\mathrm{CH}_{4}$ flux of about $1.2 \mathrm{~g} \mathrm{~m}^{-2}$ (Table 6). The observed interannual variation in the length of the period with a low WT did not exceed 10 days, and taking the temperature range in the respective seasons into account this variation would correspond to a $\mathrm{CH}_{4}$ flux variation of $0.4 \mathrm{~g} \mathrm{~m}^{-2}$ per year (Table 6).

Nevertheless, the switch-on-off function of the water table (Christensen et al., 2003; Meijide et al., 2011) does have the potential to induce substantial changes in the $\mathrm{CH}_{4}$ emissions from Skjern Meadows. For example, a permanently high water table during the warm season at a position of less than $10 \mathrm{~cm}$ below the surface would probably double the annual $\mathrm{CH}_{4}$ flux (Herbst et al., 2011a). The unusual timing and intensity of the snowmelt in early March 2010 had no visible effect on the $\mathrm{CH}_{4}$ emissions, presumably because soil moisture content was similar again between all years by mid-April (Fig. 6). Thus, the interannual difference in soil moisture was restricted to a relatively short period very early in the season with low temperatures, low microbial activity and low $\mathrm{CO}_{2}$ and $\mathrm{CH}_{4}$ fluxes.

The role of wind speed and friction velocity on $\mathrm{CH}_{4}$ emissions from wetlands is still a matter of debate (Sachs et al., 
Table 6. Sensitivity of GHG fluxes to meteorological forcing and management activities. See text for details about how the effects were quantified.

\begin{tabular}{llll}
\hline Influence factor & Observed range & Effect on $\mathrm{CO}_{2}$ flux & Effect on $\mathrm{CH}_{4}$ flux \\
\hline Seasonal average temperature & $9.7-11.8^{\circ} \mathrm{C}$ (Apr-Jun) \& 2.3-6.9 ${ }^{\circ} \mathrm{C}$ (Oct-Dec) & $60 \mathrm{~g} \mathrm{~m}^{-2} \mathrm{a}^{-1}$ & $1.2 \mathrm{~g} \mathrm{~m}^{-2} \mathrm{a}^{-1}$ \\
Snow cover duration & $0-3$ months per year & $200 \mathrm{~g} \mathrm{~m}^{-2} \mathrm{a}^{-1}$ & $\mathrm{n.s.}$ \\
Length of low WT period & $100-110$ days per year & n.s. & $0.4 \mathrm{~g} \mathrm{~m}^{-2} \mathrm{a}^{-1}$ \\
Grass cut & $0-1$ times per year & $80 \mathrm{~g} \mathrm{~m}^{-2} \mathrm{a}^{-1}$ & $\mathrm{n.s.}$ \\
Grazing & $0-4$ months per year & $180 \mathrm{~g} \mathrm{~m}^{-2} \mathrm{a}^{-1}$ & $2.7 \mathrm{~g} \mathrm{~m}^{-2} \mathrm{a}^{-1}$ \\
\hline
\end{tabular}

2008; Schrier-Uijl et al., 2010; Kroon et al., 2010). Despite the well-known fact that $\mathrm{CH}_{4}$ emissions, particularly from open water surfaces, can be triggered by changes in wind speed, it remains unclear whether this would only affect the timing or also the amount of $\mathrm{CH}_{4}$ being released into the atmosphere.

In conclusion, meteorological forcing to the extent observed between 2009 and 2011 accounted for a total variation in the annual $\mathrm{CH}_{4}$ budget of about $1.6 \mathrm{~g} \mathrm{~m}^{-2} \mathrm{a}^{-1}$ (less than a third of the observed variation), whereas the presence of cattle induced a variability of up to $2.7 \mathrm{~g} \mathrm{~m}^{-2} \mathrm{a}^{-1}$. Thus, management in terms of grazing had a larger impact than meteorological forcing, however both factors in combination did not fully explain the variability in $\mathrm{CH}_{4}$ emissions between $11 \mathrm{~g} \mathrm{~m}^{-2}$ in 2009 and $17 \mathrm{~g} \mathrm{~m}^{-2}$ in 2011 , and therefore a closer inspection of potential impacts of management activities on the $\mathrm{CH}_{4}$ flux is needed.

Several studies have shown that ruminating animals can contribute considerably to atmospheric $\mathrm{CH}_{4}$ fluxes at the ecosystem scale (Dengel et al., 2011; Detto et al., 2011; Herbst et al., 2011a; Baldocchi et al., 2012). The size of this contribution depends not only on the stocking density but also on the selection of the animals. For example, dairy cows emit more $\mathrm{CH}_{4}$ than bulls and heifers, which again emit more than sheep. An exact quantification of $\mathrm{CH}_{4}$ coming from rumination is difficult on the basis of eddy covariance data alone because the movements of the animals and the source area are not necessarily random and independent (Baldocchi et al., 2012), but a rough estimation for Skjern Meadows came to the conclusion that the $\mathrm{CH}_{4}$ emitted through rumination amounted to approximately $11 \%$ of the total annual flux in 2009 (Herbst et al., 2011a). Taking the extended grazing periods and enhanced stocking densities in the following years into account, most of the observed increase in the annual $\mathrm{CH}_{4}$ emissions could be explained by rumination. The $\mathrm{CH}_{4}$ emissions from the cattle alone would not have been enough, though, to equalize the $\mathrm{CO}_{2}$ fixation in terms of the total GHG effect. This observation agrees with Soussana et al. (2007) who found that, regarding the annual GHG budget, the $\mathrm{CH}_{4}$ emission from cattle was never enough to counterbalance the net $\mathrm{CO}_{2}$ uptake of grasslands on mineral soils where no additional $\mathrm{CH}_{4}$ emissions from the soil occur.

However, it cannot be excluded that the presence of the cattle had indirect effects on the $\mathrm{CH}_{4}$ fluxes, too. For
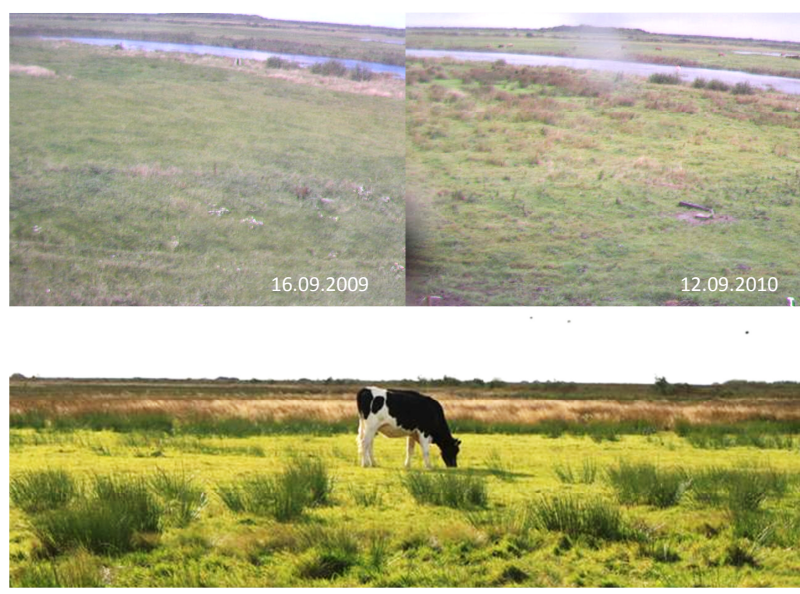

Fig. 7. Grazing cattle on Skjern Meadows promote the spreading of soft rush plants, which enable methane to bypass the aerated top soil through their aerenchyma. The upper photos show the view from the instrument mast towards the meadows in late summer, first in an undisturbed status (2009) and then after a long grazing period (2010). The lower photo illustrates that the soft rush plants are spared by the cattle.

example, it seems possible that trampling may have compacted the soil and reduced its aeration, and it became clearly visible during the investigation period that an increase in the cover of soft rush communities, as documented for the first four years following the rewetting (see Sect. 2.1), is still ongoing and accelerated when the area is grazed instead of cut (see Fig. 7). Soft rush, which is avoided by the cattle, contributes to plant mediated transport of $\mathrm{CH}_{4}$ from the soil into the atmosphere because it has aerenchymous tissues through which $\mathrm{CH}_{4}$ can bypass the aerated top soil without being oxidized. Chamber measurements of $\mathrm{CH}_{4}$ emissions from a soft rush covered, but unsaturated meadow in the same region (Schäfer et al., 2012) revealed emission rates of up to $3.3 \mathrm{mg} \mathrm{m}^{-2} \mathrm{~h}^{-1}$ (or $0.8 \mathrm{~g} \mathrm{~m}^{-2} \mathrm{~d}^{-1}$ ), amounting to almost half of the maximum eddy fluxes from wet soils observed in this study (Fig. 5). The emission rates depended linearly on the dry weight of Juncus effusus in the respective plots (Petersen et al., 2012).

The impact of the percentage cover of aerenchymous plants, and of the species composition in general, on the $\mathrm{CH}_{4}$ budget was also emphasized by Brix et al. (2001) and Levy 
et al. (2012). However, even without grazing, an increase in annual $\mathrm{CH}_{4}$ emissions over many years is likely in restored wetlands due to slow changes in the vegetation following the rewetting of a formerly drained site and due to a gradual colonisation of the soil by methanogenic microorganisms (Tuittila et al., 2000). In other case studies, Waddington and Day (2007) observed a continuous increase in $\mathrm{CH}_{4}$ emissions over four years following the restoration of a peatland, and Liikanen et al. (2006) reported an increase from 140 to $400 \mathrm{~g} \mathrm{~m}^{-2}$ between the 9 th and the 15 th year after the construction of a new wetland.

$\mathrm{CH}_{4}$ fluxes are generally much more difficult to interpret than $\mathrm{CO}_{2}$ fluxes due to a larger number of control factors and a larger spatial variability (Baldocchi et al., 2012) and also due to much fewer sites with long-term data. Future work at managed wetland sites like the one presented in this study should aim at a reliable footprint modelling and the characterisation of the spatial variability in surface properties. Ideally, this should include mobile methane sources like ruminating animals. Such studies would further have to be complemented by an annual monitoring of the plant species composition.

\subsection{General relevance of the results}

In an overview of peat soils in Scandinavia and their management, Maljanen et al. (2010) pointed out that, amongst the northern European countries, Denmark has the highest fraction (ca. $90 \%$ ) of original wetlands being drained and converted into agricultural land, but also the highest percentage of those drained areas $(>10 \%)$ being rewetted again in recent years. Also in other countries of the temperate and boreal regions, there is an increasing trend towards restoration of formerly drained wetlands (Höper et al., 2008). Skjern Meadows is Denmark's largest restoration area and considered as a role model for northern Europe. Thus it can be considered as a suitable site for a case study assessing the GHG budget of a wetland following restoration, although the development of a specific site will depend on the start conditions (Höper et al., 2008). In general, the results of this study are in line with earlier assessments of restored wetlands that concluded that such sites can become $\mathrm{CO}_{2}$ sinks after some time, depending on the development of the vegetation, and that they always are $\mathrm{CH}_{4}$ sources (Drösler et al., 2008). However, this study demonstrated that an area can also switch from sink to source and back from year to year, mostly depending on site management and extreme weather events, but less depending on gradual climatic variations. The results indicate that more long-term studies of full GHG budgets from wetlands are needed because the interannual variability in radiative forcing of a specific land use type can be particularly large where more than one GHG is affected and where different GHGs are controlled by different environmental factors. Whilst the response of GHG fluxes to climatic factors is increasingly well understood, many global models and prediction schemes fail to account for site management factors.

Some of the first flux tower sites that were equipped with sensors accounting for the full GHG balance (e.g. Rinne et al., 2007; Sachs et al., 2008; Kroon et al., 2010) have meanwhile been in operation for several years, and this will soon make a more comprehensive assessment of interannual variations in the total GHG flux from wetland sites possible. At present, comparisons between such sites are still hampered by the fact that there is as yet no standardised $\mathrm{CH}_{4}$ flux measurement and gap filling protocol in place, as it is the case for $\mathrm{CO}_{2}$ fluxes as a result of the "Euroflux" and "Fluxnet" activities (Aubinet et al., 2000; Papale et al., 2006). Recent instrument intercomparisons are encouraging (Detto et al., 2011) though, and both a standardisation of eddy flux measurements and a complementary application of chamber measurements at flux tower sites could help improving both the process understanding and the transferability of results to other climate and vegetation types where $\mathrm{CO}_{2}$ and $\mathrm{CH}_{4}$ contribute to the atmospheric GHG budget.

\section{Conclusions}

This case study has demonstrated that the annual $\mathrm{CO}_{2}$ fluxes above a restored wetland were mainly controlled by site management and growing season length and that the annual $\mathrm{CH}_{4}$ emissions depended strongly on grazing effects. The interannual variability was higher for the $\mathrm{CO}_{2}$ than for the $\mathrm{CH}_{4}$ fluxes, but the site remained a net $\mathrm{CO}_{2}$ and a net carbon sink. However, adding the $\mathrm{CH}_{4}$ emissions as $\mathrm{CO}_{2}$ equivalents to the balance made the sign of the total GHG budget switch between years. Somewhat unexpectedly, the site turned into a significant GHG source in the coolest and driest year. It was shown that site management played a large role in this observation, and with an increasing amount of former wetlands being restored there is a need to improve the prediction of the radiative forcing of wetland ecosystems by incorporating such anthropogenic effects. The eddy covariance technique has proven to be a suitable tool to monitor full GHG budgets from a wide range of wetland sites, and more such flux studies will be needed to understand the role of these ecosystems and their management in the atmospheric greenhouse gas budget.

Acknowledgements. The study was part of the HOBE (Hydrological observatory and exploratorium) project, which is funded by the Villum Foundation, and it was additionally supported by the Danish Council for Strategic Research through the EcoClim project. The authors are very grateful to Lars Mejlgaard Rasmussen (Aarhus University, Denmark) for technical assistance in the field.

This Open Access Publication is funded by the University of Göttingen.

Edited by: P. Stoy 


\section{References}

Allard, V., Soussana, J.-F., Falcimagne, R., Berbigier, P., Bonnefond, J. M., Ceschia, E., D’hour, P., Hénault, C., Laville, P., Martin, C., and Pinarès-Patino, C.: The role of grazing management for the net biome productivity and greenhouse gas budget $\left(\mathrm{CO}_{2}\right.$, $\mathrm{N}_{2} \mathrm{O}$ and $\mathrm{CH}_{4}$ ) of semi-natural grassland, Agr. Ecosyst. Environ., 121, 47-58, 2007.

Andersen, J. M., Jessen, K., Larsen, B. B., Bundgaard, P., Glüsing, H., Illum, T., Hansen, L. B., Damgaard, O., Koed, A., Baktoft, H., Jensen, J. H., Linnemann, M., Ovesen, N. B., Svendsen, L. M., Bregnballe, T., Skriver, J., Baattrup-Pedersen, A., Pedersen, M. L., Madsen, A. B., Amstrup, O., and Bak, M.: Restaurering af Skjern Å, Sammenfatning af overvågningsresultater 1999-2003, Environmental Research Institute, University of Aarhus, 96 pp., NERI Technical Report no. 531, 2005 (in Danish).

Aubinet, M., Grelle, A., Ibrom, A., Rannik, Ü., Moncrieff, J., Foken, T., Kowalski, A., Martin, P., Berbigier, P., Bernhofer, C., Clement, R., Elbers, J., Granier, A., Grünwald, T., Morgenstern, K., Pilegaard, K., Rebmann, C., Snijders, W., Valentini, R., and Vesala, T.: Estimates of the annual net carbon and water exchange of European forests: the EUROFLUX methodology, Adv. Ecol. Res., 30, 113-175, 2000.

Aurela, M., Laurila, T., and Tuovinen, J.-P.: The timing of snow melt controls the annual $\mathrm{CO}_{2}$ balance in a subarctic fen, Geophys. Res. Lett., 31, L16119, doi:10.1029/2004GL020315, 2004.

Baldocchi, D., Falge, E., Gu, L., Olson, R., Hollinger, D., Running, S., Anthoni, P., Bernhofer, C., Davis, K., Evans, R., Fuentes, J., Goldstein, A., Katul, G., Law, B., Lee, X., Malhi, Y., Meyers, T., Munger, W., Oechel, W., Paw U, K. T., Pilegaard, K., Schmid, H. P., Valentini, R., Verma, S., Vesala, T., Wilson, K., and Wofsy, S.: FLUXNET: A new tool to study the temporal and spatial variability of ecosystem-scale carbon dioxide, water vapour, and energy flux densities, B. Am. Meteorol. Soc., 82, 2415-2434, 2001.

Baldocchi, D., Detto, M., Sonnentag, O., Verfaillie, J., Teh, Y. A., Silver, W., and Kelly, N. M.: The challenges of measuring methane fluxes and concentrations over a peatland pasture, Agr. Forest Meteorol., 153, 177-187, 2012.

Brix, H., Sorrell, B. K., and Lorenzen, B.: Are Phragmitesdominated wetlands a net source or net sink of greenhouse gases?, Aquat. Bot., 69, 313-324, 2001.

Bubier, J. L., Moore, T. R., and Roulet, N. T.: Methane emissions from wetlands in the midboreal region of northern Ontario, Canada. Ecol., 74, 2240-2254, 1993.

Burba, G. G., McDermitt, D. K., Grelle, A., Anderson, D. J., and $\mathrm{Xu}$, L.: Addressing the influence of instrument surface heat exchange on the measurements of $\mathrm{CO}_{2}$ flux from open-path gas analyzers, Glob. Change Biol., 14, 1854-1876, 2008.

Byrne, K. A., Kiely, G., and Leahy, P.: Carbon sequestration determined using farm scale carbon balance and eddy covariance, Agr. Ecosyst. Environ., 121, 357-364, 2007.

Christensen, T. R., Ekberg, A., Ström, L., Mastepanov, M., Panikov, N., Öquist, M., Svensson, B. H., Nykänen, H., Martikainen, P. J., and Oskarsson, H.: Factors controlling large scale variations in methane emissions from wetlands, Geophys. Res. Lett., 30, 1414, doi:10.1029/2002GL016848, 2003.

Crill, P. M., Bartlett, K. B., Harriss, R. C., Gorham, E., Verry, E. S., Sebacher, D. I., Madzar, L., and Sanner, W.: Methane flux from Minnesota peatlands, Global Biogeochem. Cy., 2, 371-384, 1988.
Dengel, S., Levy, P. E., Grace, J., Jones, S. K., and Skiba, U. M.: Methane emissions from sheep pasture, measured with an openpath eddy covariance system, Glob. Change Biol., 17, 35243533, 2011.

Detto, M., Verfaillie, J., Anderson, F., Xu, L., and Baldocchi, D.: Comparing laser-based open- and closed-path analyzers to measure methane fluxes using the eddy covariance method, Agr. Forest Meteorol., 151, 1312-1324, 2011.

Drösler, M., Freibauer, A., Christensen, T. R., and Friborg, T.: Observations and status of peatland greenhouse gas emissions in Europe, in: The continental-scale greenhouse gas balance of Europe, edited by: Dolman, A. J., Freibauer, A., and Valentini, R., Ecological Studies, 203, Springer Verlag, 243-261, 2008.

Elsgaard, L., Görres, C.-M., Hoffmann, C. C., Blicher-Mathiesen, G., Schelde, K., and Petersen, S. O.: Net ecosystem exchange of $\mathrm{CO}_{2}$ and carbon balance for eight temperate organic soils under agricultural management, Agr. Ecosyst. Environ., 162, 5267, 2012.

Eugster, W. and Plüss, P.: A fault-tolerant eddy covariance system for measuring $\mathrm{CH}_{4}$ fluxes, Agr. Forest Meteorol., 150, 841-851, 2010.

Foken, T., Göckede, M., Mauder, M., Mahrt, L., Amiro, B., and Munger, W.: Post-field data quality control, in: Handbook of Micrometeorology, edited by: Lee, X., 181-208, 2004.

Forbrich, I., Kutzbach, L., Wille, C., Becker, T., Wu, J., and Wilmking, M.: Cross-evaluation of measurements of peatland methane emissions on microform and ecosystem scales using high-resolution landcover classification and source weight modelling, Agr. Forest Meteorol., 151, 864-874, 2011.

Friborg, T., Soegaard, H., Christensen, T. R., Lloyd, C. R., and Panikov, N. S.: Siberian wetlands: Where a sink is a source, Geophys. Res. Lett/, 30, 2129, doi:10.1029/2003GL017797, 2003.

Frolking, S. E., Bubier, J. L., Moore, T. R., Ball, T., Bellisario, L. M., Bhardwaj, A., Carroll, P., Crill, P. M., Lafleur, P. M., McCaughey, J. H., Roulet, N. T., Suyker, A. E., Verma, S. B., Waddington, J. M., and Whiting, G. J.: Relationship between ecosystem productivity and photosynthetically active radiation for northern peatlands, Global Biogeochem. Cy., 12, 115-126, 1998.

Gleason, R. A., Tangen, B. A., Browne, B. A., and Euliss Jr., N. H.: Greenhouse gas flux from cropland and restored wetlands on the Prairie Pothole Region, Soil Biol. Biochem., 41, 2501-2507, 2009.

Hatala, J. A., Detto, M., Sonnentag, O., Deverel, S. J., Verfaillie, J., and Baldocchi, D. D.: Greenhouse gas $\left(\mathrm{CO}_{2}, \mathrm{CH}_{4}, \mathrm{H}_{2} \mathrm{O}\right)$ fluxes from drained and flooded agricultural peatlands in the Sacramento-San Joaquin Delta, Agr. Ecosyst. Environ., 150, 1$18,2012$.

Hendriks, D. M. D., van Huissteden, J., Dolman, A. J., and van der Molen, M. K.: The full greenhouse gas balance of an abandoned peat meadow, Biogeosciences, 4, 411-424, doi:10.5194/bg-4411-2007, 2007.

Hendriks, D. M. D., Dolman, A. J., van der Molen, M. K., and van Huissteden, J.: A compact and stable eddy covariance set-up for methane measurements using off-axis integrated cavity output spectroscopy, Atmos. Chem. Phys., 8, 431-443, doi:10.5194/acp-8-431-2008, 2008.

Herbst, M., Friborg, T., Ringgaard, R., and Soegaard, H.: Interpreting the variations in atmospheric methane fluxes observed above 
a restored wetland, Agr. Forest Meteorol., 151, 841-853, $2011 \mathrm{a}$. Herbst, M., Friborg, T., Ringgaard, R., and Soegaard, H.: Catchmentwide atmospheric greenhouse gas exchange as influenced by land use diversity, Vadose Zone J., 10, 67-77, 2011 b.

Höper, H., Augustin, J., Cagampan, J. P., Drösler, M., Lundin, L., Moors, E., Vasander, H., Waddington, J. M., and Wilson, D.: Restoration of peatlands and greenhouse gas balances, in: Peatlands and Climate Change, edited by: Starck, M., International Peat Society, Saarijärvi, Finland, 182-210, 2008.

Houborg, R., Anderson, M. C., Norman, J. M., Wilson, T., and Meyers, T.: Intercomparison of a "bottom-up" and "top-down" modelling paradigm for estimating carbon and energy fluxes over a variety of vegetative regimes across the U.S., Agr. Forest Meteorol., 149, 2162-2182, 2009.

IPCC: Climate Change: The Physical Science Basis. Contribution of Working Group I to the Fourth Assessment Report of the Intergovernmental Panel on Climate Change. Cambridge University Press, Cambridge, UK and New York, NY, USA, 2007.

Jacobs, C. M. J., Jacobs, A. F. G., Bosveld, F. C., Hendriks, D. M. D., Hensen, A., Kroon, P. S., Moors, E. J., Nol, L., SchrierUijl, A., and Veenendaal, E. M.: Variability of annual $\mathrm{CO}_{2}$ exchange from Dutch grasslands, Biogeosciences, 4, 803-816, doi:10.5194/bg-4-803-2007, 2007.

Klumpp, K., Tallec, T., Guix, N., and Soussana, J.-F.: Long-term impacts of agricultural practices and climatic variability on carbon storage in a permanent pasture, Glob. Change Biol., 17, 3534-3545, 2011.

Kroon, P. S., Schrier-Uijl, A. P., Hensen, A., Veenendaal, E. M., and Jonker, H. J. J.: Annual balances of $\mathrm{CH}_{4}$ and $\mathrm{N}_{2} \mathrm{O}$ from a managed fen meadow using eddy covariance flux measurements, Eur. J. Soil Sci., 61, 773-784, 2010.

Levy, P. E., Burden, A., Cooper, M. D. A., Dinsmore, K. J., Drewer, J., Evans, C., Fowler, D., Gaiawyn, J., Gray, A., Jones, S. K., Jones, T., McNamara, N. P., Mills, R., Ostle, N., Sheppard, L. J., Skiba, U., Sowerby, A., Ward, S. E., and Zieliński, P.: Methane emissions from soils: synthesis and analysis of a large UK data set, Glob. Change Biol., 18, 1657-1669, 2012.

Liikanen, A., Huttunen, J. T., Karjalainen, S. M., Heikkinen, K., Väisänen, T. S., Nykänen, H., and Martikainen, P. J.: Temporal and seasonal changes in greenhouse gas emissions from a constructed wetland purifying peat mining runoff waters, Ecol. Eng., 26, 241-251, 2006.

Lloyd, C. R.: Annual carbon balance of a managed wetland meadow in the Somerset Levels, UK, Agr. Forest Meteorol., 138, 168179,2006

Lloyd, J. and Taylor, J. A.: On the temperature dependence of soil respiration, Funct. Ecol., 8, 315-323, 1994.

Maljanen, M., Sigurdsson, B. D., Guðmundsson, J., Óskarsson, H., Huttunen, J. T., and Martikainen, P. J.: Greenhouse gas balances of managed peatlands in the Nordic countries - present knowledge and gaps, Biogeosciences, 7, 2711-2738, doi:10.5194/bg7-2711-2010, 2010.

Marquardt, D. W.: An algorithm for least squares estimation of parameters, J. Soc. Industr. Appl. Math., 11, 431-441, 1963.

Meijide, A., Manca, G., Goded, I., Magliulo, V., di Tommasi, P., Seufert, G., and Cescatti, A.: Seasonal trends and environmental controls of methane emissions in a rice paddy field in Northern Italy, Biogeosciences, 8, 3809-3821, doi:10.5194/bg8-3809-2011, 2011.
Nielsen, I. and Schierup, H.-H.: Skjern Å, Aarhus Universitetsforlag, 219 pp., 2007.

Papale, D., Reichstein, M., Aubinet, M., Canfora, E., Bernhofer, C., Kutsch, W., Longdoz, B., Rambal, S., Valentini, R., Vesala, T., and Yakir, D.: Towards a standardized processing of Net Ecosystem Exchange measured with eddy covariance technique: algorithms and uncertainty estimation, Biogeosciences, 3, 571-583, doi:10.5194/bg-3-571-2006, 2006.

Parmentier, F. J. W., van der Molen, M. K., de Jeu, R. A. M., Hendriks, D. M. D., and Dolman, A. J.: $\mathrm{CO}_{2}$ fluxes and evaporation on a peatland in the Netherlands appear not affected by water table fluctuations, Agr. Forest Meteorol., 149, 1201-1208, 2009.

Pedersen, M. L., Andersen, J. M., Nielsen, K., and Linnemann, M.: Restoration of Skjern River and ist valley: Project description and general ecological changes in the project area, Ecol. Eng., 30, 131-144, 2007.

Petersen, S. O., Hoffmann, C. C., Schäfer, C.-M., BlicherMathiesen, G., Elsgaard, L., Kristensen, K., Larsen, S. E., Torp, S. B., and Greve, M. H.: Annual emissions of $\mathrm{CH}_{4}$ and $\mathrm{N}_{2} \mathrm{O}$, and ecosystem respiration, from eight organic soils in Western Denmark managed by agriculture, Biogeosciences, 9, 403-422, doi:10.5194/bg-9-403-2012, 2012.

Reichstein, M., Falge, E., Baldocchi, D., Papale, D., Aubinet, M., Berbigier, P., Bernhofer, C., Buchmann, N., Gilmanov, T., Granier, A., Grünwald, T., Havránková, K., Ilvesniemi, H., Janous, D., Knohl, A., Laurila, T., Lohila, A., Loustau, D., Matteucci, G., Meyers, T., Miglietta, F., Ourcival, J.-M., Pumpanen, J., Rambal, S., Rotenberg, E., Sanz, M., Tenhunen, J., Seufert, G., Vaccari, F., Vesala, T., Yakir, D., and Valentini, R.: On the separation of net ecosystem exchange into assimilation and ecosystem respiration: review and improved algorithm, Glob. Change Biol., 11, 1424-1439, 2005.

Ringgaard, R., Friborg, T., Herbst, M., and Soegaard, H.: Energy fluxes above three disparate surfaces in a temperate meso-scale coastal catchment, Vadose Zone J., 10, 54-66, 2011.

Rinne, J., Riutta, T., Pihlatie, M., Aurela, M., Haapanala, S., Tuovinen, J.-P., and Tuittila, E.-S.: Annual cycle of methane emission from a boreal fen measured by the eddy covariance technique, Tellus B, 59, 449-457, 2007.

Roulet, N. T., Ash, R., and Moore, T. R.: Low boreal wetlands as a source of atmospheric methane, J. Geophys. Res., 97, 37393749, 1992.

Ruimy, A., Jarvis, P. G., Baldocchi, D. D., and Saugier, B.: $\mathrm{CO}_{2}$ fluxes over plant canopies and solar radiation: a review, Adv. Ecol. Res., 26, 1-68, 1995.

Sachs, T., Wille, C., Boike, J., and Kutzbach, L.: Environmental controls on ecosystem-scale $\mathrm{CH}_{4}$ emission from polygonal tundra in the Lena River Delta, Siberia, J. Geophys. Res., 113, G00A03, doi:10.1029/2007JG000505, 2008.

Schäfer, C. K., Elsgaard, L., Hoffmann, C. C., and Petersen, S. O.: Seasonal methane dynamics in three temperate grasslands on peat, Plant Soil, 357, 339-353, doi:10.1007/s11104-012-1168-9, 2012.

Schelde, K., Thomsen, A. G., Heidmann, T., Schjønning, P., and Jansson, P.-E.: Diurnal fluctuations of water and heat flows in a bare soil, Water Resour. Res., 34, 2919-2929, 1998.

Schrier-Uijl, A. P., Kroon, P. S., Hensen, A., Leffelaar, P. A., Berendse, F., and Veenendaal, E. M.: Comparison of chamber and eddy covariance-based $\mathrm{CO}_{2}$ and $\mathrm{CH}_{4}$ emission estimates in 
a heterogeneous grass ecosystem on peat, Agr. Forest Meteorol., 150, 825-831, 2010.

Schulze, E. D., Luyssaert, S., Ciais, P., Freibauer, A., Janssens, I. A., Soussana, J. F., Smith, P., Grace, J., Levin, I., Thiruchittampalam, B., Heimann, M., Dolman, A. J., Valentini, R., Bousquet, P., Peylin, P., Peters, W., Rödenbeck, C., Etiope, G., Vuichard, N., Wattenbach, M., Nabuurs, G. J., Poussi, Z., Nieschulze, J., and Gash, J. H. C.: Importance of methane and nitrous oxide for Europe's terrestrial greenhouse-gas balance, Nat. Geosci., 2, 842-850, 2009.

Soussana, J. F., Allard, V., Pilegaard, K., Ambus, P., Amman, C., Campbell, C., Ceschia, E., Clifton-Brown, J., Czobel, S., Domingues, R., Flechard, C., Fuhrer, N., Hensen, A., Horvath, L., Jones, M., Kasper, G., Martin, C., Nagy, Z., Neftel, A., Raschi, A., Baronti, S., Rees, R. M., Skiba, U., Stefani, P., Manca, G., Sutton, M., Tuba, Z., and Valentini, R.: Full accounting of the greenhouse gas $\left(\mathrm{CO}_{2}, \mathrm{~N}_{2} \mathrm{O}, \mathrm{CH}_{4}\right)$ budget of nine European grassland sites, Agr. Ecosyst. Environ., 121, 121-134, 2007.
Tuittila, E.-S., Komulainen, V.-M., Vasander, H., Nykänen, H., Martikainen, P. J., and Laine, J.: Methane dynamics of a restored cutaway peatland, Glob. Change Biol., 6, 569-581, 2000.

Van Beek, C. L., Pleijter, M., and Kuikman, P. J.: Nitrous oxide emissions from fertilized and unfertilized grasslands on peat soils, Nutr. Cycl. Agroecosys., 89, 453-461, 2011.

Waddington, J. M. and Day, S. M.: Methane emissions from a peatland following restoration, J. Geophys. Res., 112, G03018, doi:10.1029/2007JG000400, 2007.

Webb, E. K., Pearman, G. I., and Leuning, R.: Correction of flux measurements for density effects due to heat and water vapor transfer, Q. J. Roy. Meteorol. Soc., 106, 85-100, 1980.

Whiting, G. J. and Chanton, J. P.: Greenhouse carbon balance of wetlands: methane emission versus carbon sequestration. Tellus B, 53, 521-528, 2001.

Wilczak, J., Oncley, S., and Stage, S. A.: Sonic anemometer tilt correction algorithms, Bound.-Lay. Meteorol., 99, 127-150, 2001. 